\title{
FLORISTIC ASSESSMENT OF BARDA HILLS, GUJARAT
}

\author{
R D Raviya \\ Department of Life Sciences, Bhakta Kavi Narsinh Mehta University, \\ Junagadh, Gujarat, India. \\ rdraviya@gmail.com
}

Communicated: 30.07 .20

Revision : $10.08 .20 \& 30.8 .2020$

Accepted: 16.09.2020

Published: 30.09 .2020

\begin{abstract}
:
The Barda Hills (sanctuary) from a compact block of about 192.31 sq. kms lying between parallels of latitude $21^{\circ} 40^{\prime}$ to $21^{\circ} 55^{\prime}$ North and meridian of longitude $69^{\circ} 40^{\prime}$ to $69^{\circ} 50^{\prime}$ East. The average rainfall is $500-600 \mathrm{~mm}$. The average maximum temperature is $42.5^{\circ} \mathrm{C}$ in May, and the minimum temperature is $6.0^{\circ} \mathrm{C}$ in January. The present study enumerated 368 species, which belonged to 268 genera and 80 families of Angiosperms. Herbs contribute more than $50 \%$ (i.e. $54.34 \%$ ), followed by trees, shrubs and climbers which were $16.04 \%, 22.56 \%$ and $7.06 \%$, respectively. Overall ratio of genera to species was found 1: 1.37. The higher percentage of Fabaceae was more dominant family in present study with 11 genera and 32 species.
\end{abstract}

Key words: - Barda Hills, Floristic assessment

\section{INTRODUCTION:}

Barda Sanctuary is spread in two districts Porbandar and Jamnagar, Gujarat State of India. The part of Barda Sanctuary, which falls under the Porbandar district, is known as "Rana Barda", while the portion of Barda sanctuary, which falls under the Jamnagar district, is known as "Jam Barda". The Barda Sanctuary from a compact block of about 192.31 sq. kms lying between parallels of latitude $21^{\circ} 40^{\prime}$ to $21^{\circ}$ $55^{\prime}$ North and meridians of longitude $69^{\circ} 40^{\prime}$ to $69^{\circ}$ 50' East. The Barda Sanctuary is hilly area. At places vary gentle slopes are noted but there are conspicuous absence of undulating ground. The climate is generally hot and dry. The average rainfall is $500-600 \mathrm{~mm}$. The average maximum temperature is $42.5^{\circ} \mathrm{C}$ in May, and the minimum temperature is $6.0^{\circ} \mathrm{C}$ in January. The climatic conditions support dry deciduous nature of the forest in studied area. Dominant plants were
Acacia senegal, Lantana camara, Cassia auriculata and Manilkara hexandra.

Ecosystems further differ from genus and species in that these explicitly include abiotic components, being partly determined by soil parent material and climate. Conservation of the present diversity is, therefore, the only approach that balances people's short and long-term needs from natural resources (Verma et. al, 2000).

\section{MATERIAL \& METHODS:}

Barda Sanctuary is spread in two districts Porbandar and Jamnagar, Gujarat State of India. The part of Barda Sanctuary, which falls under the Porbandar district, is known as "Rana Barda", while the portion of Barda sanctuary, which falls under the Jamnagar district, is known as "Jam Barda". The Barda Sanctuary from a compact block of about 192.31 sq. kms lying between parallels of latitude $21^{\circ} 40^{\prime}$ to $21^{\circ}$ $55^{\prime}$ North and meridians of longitude $69^{\circ} 40^{\prime}$ to 
$69^{\circ} 50^{\prime}$ East. The Barda Sanctuary is hilly area. At places vary gentle slopes are noted but there are conspicuous absence of undulating ground. The climate is generally hot and dry. The average rainfall is $500-600 \mathrm{~mm}$. The average maximum temperature is $42.5^{\circ} \mathrm{C}$ in May, and the minimum temperature is $6.0^{\circ} \mathrm{C}$ in January. The climatic conditions support dry deciduous nature of the forest in studied area. Dominant plants were Acacia senegal, Lantana camara, Cassia auriculata and Manilkara hexandra.

Ecosystems further differ from genus and species in that these explicitly include abiotic components, being partly determined by soil parent material and climate. Conservation of the present diversity is, therefore, the only approach that balances people's short and long-term needs from natural resources (Verma et. al, 2000).

The arrangement of families follows Bentham and Hooker's system of classification. Survey of the forest were made fortnightly throughout the year and plants of various seasons were examined and identified. Information was collected on the emergence; flowering period, occurrence, habitat and local name. Vegetation was studied by Braun Blanquet (1932), Oosting (1958), Thakkar J I (1910) and Pandeya et al. (1967).

\section{RESULTS AND DISCUSSION:}

The present study enumerated 368 species, which belonged to 268 genera and 80 families of Angiosperms (Table 1). According to these numbers, Simpson's Index was 0.377, Index of Similarity was 0.623, Reciprocal Index was 2.653, Shannon-Wiener Index was 1.148, and Evenness Index was 0.828 indicating that the area under study has reasonable high diversity in the number of plant species.

Out of these, Dicotyledons contributed 318 plant species belonging to 226 genera and 69 families, which was quite higher than that of Monocotyledons. In Dicotyledons, Fabaceae and Euphorbiaceae families were highly represented. The Monocotyledons contributed only 50 species belonging to 42 genera and 11 families. In Monocotyledon, Poaceae and Cyperaceae families were highly represented.

The proportion of the Monocotyledons to Dicotyledons was recorded 1:6.27 of families, 1 : 5.38 of genera and 1: 6.38 of species (Table 2). The ratio for Dicotyledons family to genera (genus) was recorded at 1: 3.27, family to species 1: 4.60, and genera to species 1: 1.40, and for Monocotyledons ratio of family to genera 1: 3.81 , family to species $1: 4.54$, and genera to species 1: 1.19 found. Overall ratio of genera to species was found 1: 1.37, which is rather low in comparison to the ratio for whole of India $(1: 7)$, but is more or less in conformity with the ratio of Delhi State $(1: 1.63)$ as reported by Maheshwari (1963) and West Rajasthan (1:1.9) reported by Bhandari (1978).

The habit approach revealed that out of 368 flowering plants, herbs contribute more than $50 \%$ (i.e. $54.34 \%$ ), followed by trees, shrubs and climbers which were $16.04 \%, 22.56 \%$ and $7.06 \%$, respectively (Table 3). The higher percentage of herbs in the area could be attributed to edaphic and peculiar climate conditions like meagre rainfall and high temperature. During summer, when the temperature becomes severe and the soil becomes intolerable to the plants, and the result is that only short living plants like annual herbs are only favoured because herbs can complete 
I J R B A T, Issue (VIII), Vol. III, Sept 2020: 231-235

A Double-Blind Peer Reviewed \& Refereed Journal
OPEN ACCESS

e-ISSN $2347-517 X$

Original Article their life cycle before the commencement of the dry season and set seed during the summer. Hence, the proper utilisation of climatic and edaphic factors is often responsible for such type of distribution pattern. While studying the temperate and tropical forest types, Smith (1973) reported that an increased structural integrity of the forest would lead to a proper utilisation of climatic and edaphic conditions.

Fabaceae was more dominant family in present study with 11 genera and 32 species, followed by Poaceae with 19 genera and 22 species and Euphorbiaceae with 9 genera and 19 species (Table 4).

A comparison of the present dominant family in the area of study with other regions of Gujarat State yields a very interesting result. The five dominant families of Barda Hills have been compared to those in the other regions of Gujarat (Table 5) viz. Saurashtra region (Santapau and Janardhan, 1966); Gujarat State (Shah, 1978); South Gujarat (Yadav, 1979); Goghamahal (Vora and Patel 1981); Victoria Park Reserve forest (Patel, 1982); and Gir Forest (Kotiwar, 1995).

It is evident from above Table that most of the dominant families in the present study have been reported earlier from different regions of Gujarat State, but the order of dominance is different. However, the legumes and grasses occupy the first and second place in all these regions of Gujarat, except South Gujarat, where grasses occupied the first position.

Thakkar (1910) reported 611 plants in his voluminous work on Barda Hills of 'Kathiawad', while comparing our data we have observed that about 84 plants are recorded by us which are not recorded by Thakkar (1910) at the same time 89 plants, which are recorded by Thakkar
(1910), are missing in our survey. Thus we can say that 89 plants have been removed from the area and 84 new species as occupied these habitat. About 284 plants are common in both the lists.

\section{REFERENCES:}

Bhandari, M.M. 1978. Flora of the Indian Desert. Scientific Publishers, Jodhpur.

Braun-Blanquet, J. 1932. Plant sociology, trans. By Fuller and Conard. Mc Graw Hill Book Co. Inc. New York and London.

Kotiwar, O.M. 1995. Ecological and Taxonomical study of dry deciduous Gir forest. Ph.D. Thesis, Bhavnagar University, Bhavnagar.

Maheshwari, J.K. 1963. The flora of Delhi. C.S.I.R., New Delhi.

Oosting, H. J. 1958. The study of Plants communities W. H. Frceman and co. San Francisco. U.S.A.

Pandeya, S.C., Pandya, S.M., Murthy, M.S and Kuruvilla, K. 1967. Forest ecosystem. Classification of forest vegetation with reference to forests in the River Narmada catchment Area. J. Ind. Bot. Soc.46: 412427.

Patel, B.P. 1982. Ecological Survey of the Reserved forest (Victoria Park) near Bhavnagar. Ph.D. thesis, Bhavnagar University, Bhavnagar.

Santapau, H and Janardhan, K.P., 1966. The flora of Saurashtra. Bull. Bot. Surv. India. 8: $1-58$.

Shah, G.L. 1978. Flora of Gujarat State. Vol. I \& II. Sardar Patel University Press, Anand.

Smith A. P. 1973. Stratification in temperate and tropical forests. Am. Nat. 107: 671-683.

Thakkar, J.I. 1910. Vanaspati Shashtra. Reprint 1998. Pravin Pustak Bhandar, Rajkot. 
Verma, R.K., Shadangi, D.K and Totey, N.G. 2000. Effect of Dalbergia sissoo Roxb. And dendrocalamus strictus (Roxb.) Plantations on enhancement of biological diversity in degraded land. J. Trop. For. 16: 36-44.

Vora, U.A and Patel, B.K., 1981. The vegetation of Goghamahal and its biological spectrum. Geobios, 8: 211-214.

Table 1: Number of families, genera and species of each class

\begin{tabular}{|c|c|c|c|c|c|c|}
\hline \multirow{2}{*}{ Class } & \multicolumn{2}{|c|}{ Families } & \multicolumn{2}{c|}{ Genera } & \multicolumn{2}{c|}{ Species } \\
\cline { 2 - 7 } & NO. & $\%$ & No. & $\%$ & No. & $\%$ \\
\hline Dicotyledons & 69 & 86.25 & 226 & 84.33 & 318 & 86.41 \\
\hline Monocotyledons & 11 & 13.75 & 42 & 15.67 & 50 & 13.59 \\
\hline Total & $\mathbf{8 0}$ & $\mathbf{1 0 0 . 0}$ & $\mathbf{2 6 8}$ & $\mathbf{1 0 0 . 0}$ & $\mathbf{3 6 8}$ & $\mathbf{1 0 0 . 0}$ \\
\hline
\end{tabular}

Table 2: Ratio between Monocotyledons, Dicotyledons, and Overall

\begin{tabular}{|l|l|}
\hline \multicolumn{2}{|c|}{ Monocotyledons to Dicotyledons } \\
\hline Family to Family & $1: 6.27$ \\
\hline Genera to Genera & $1: 5.38$ \\
\hline Species to Species & $1: 6.38$ \\
\hline & $1: 3.81$ \\
\hline Family to genera & $1: 4.54$ \\
\hline Family to species & $1: 1.19$ \\
\hline Genera to species & $1: 3.27$ \\
\hline \multicolumn{2}{|c|}{ Dicotyledons } \\
\hline Family to genera & $1: 4.60$ \\
\hline Family to species & $1: 1.40$ \\
\hline Genera to species & $1: 3.35$ \\
\hline & $1: 4.60$ \\
\hline Family to genera & $1: 1.37$ \\
\hline Family to species &
\end{tabular}

Yadav, S.R. 1979. A contribution to the floristic and phytosociology of some parts of South Gujarat. Ph.D. Thesis, S. P. University, Vallabh Vidhyanagar. 
Table 3: Number and percentage of species belonging to different habits

\begin{tabular}{|l|l|l|}
\hline Habits & Total species & \% \\
\hline Herbs & 200 & 54.34 \\
\hline Shrubs & 83 & 22.56 \\
\hline Trees & 59 & 16.04 \\
\hline Climbers & 26 & 07.06 \\
\hline Total & $\mathbf{3 6 8}$ & $\mathbf{1 0 0 . 0}$ \\
\hline
\end{tabular}

Table 4: Number with percentage of genera and species of the dominant families of Barda Hills

\begin{tabular}{|l|l|c|c|c|c|}
\hline $\begin{array}{l}\text { Sr. } \\
\text { No. }\end{array}$ & Families & $\begin{array}{c}\text { No. of } \\
\text { genera }\end{array}$ & \% & $\begin{array}{c}\text { No. of } \\
\text { species }\end{array}$ & \% \\
\hline 1. & Fabaceae & 11 & 4.10 & 32 & 8.69 \\
\hline $\mathbf{2 .}$ & Poaceae & 19 & 7.08 & 22 & 5.97 \\
\hline 3. & Euphorbiaceae & 09 & 3.35 & 19 & 5.16 \\
\hline 4. & Caesalpiniaceae & 07 & 2.61 & 18 & 4.89 \\
\hline $\mathbf{5 .}$ & Asteraceae & 13 & 4.85 & 14 & 3.80 \\
\hline
\end{tabular}

Table 5: Comparison of five dominant families of Barda Hills with different regions of Gujarat

\begin{tabular}{|c|c|c|c|c|c|c|}
\hline $\begin{array}{c}\text { Barda Hills } \\
\text { (Present } \\
\text { study) }\end{array}$ & $\begin{array}{c}\text { Saurashtr } \\
\text { a } \\
\text { Region }\end{array}$ & $\begin{array}{c}\text { Gujarat } \\
\text { State }\end{array}$ & $\begin{array}{c}\text { South } \\
\text { Gujarat }\end{array}$ & $\begin{array}{c}\text { Goghama } \\
\mathbf{1}\end{array}$ & $\begin{array}{c}\text { Victoria } \\
\text { Park }\end{array}$ & $\begin{array}{c}\text { Gir } \\
\text { Forest. }\end{array}$ \\
\hline Fabaceae & Fabaceae & Fabaceae & Poaceae & Fabaceae & Fabaceae & Fabaceae \\
\hline Poaceae & Poaceae & Poaceae & Fabaceae & Poaceae & Poaceae & Poaceae \\
\hline Euphorbiaceae & Asteraceae & $\begin{array}{c}\text { Cyperacea } \\
\text { e }\end{array}$ & Cyperaceae & $\begin{array}{c}\text { Euphorbiac } \\
\text { eae }\end{array}$ & $\begin{array}{c}\text { Euphorbiac } \\
\text { eae }\end{array}$ & Asteraceae \\
\hline Caesalpiniaceae & Malvaceae & Asteraceae & Asteraceae & Asteraceae & Asteraceae & Acanthaceae \\
\hline Asteraceae & Acanthaceae & $\begin{array}{c}\text { Acanthace } \\
\text { ae }\end{array}$ & $\begin{array}{c}\text { Euphorbiac } \\
\text { eae }\end{array}$ & Malvaceae & Malvaceae & Euphorbiaceae \\
\hline
\end{tabular}

